\title{
THE EFFECT OF THE FARM SIZE ON MILK TRAITS OF COWS
}

\section{Kučević ${ }^{1}$, S. Trivunović ${ }^{1}$, M. Radinović ${ }^{1}$, M.Plavšić ${ }^{1}$, Z. Skalicki ${ }^{2}$, P. Perišić $^{2}$}

\author{
${ }^{1}$ Faculty of Agriculture, Department of Animal Science, 21000, Novi Sad, Republic of Serbia \\ ${ }^{2}$ Faculty of Agriculture, Zootechnical Institute, 11080, Belgrade-Zemun, Republic of Serbia \\ Corresponding author: \\ Corresponding author: denis.kucevic@stocarstvo.edu.rs \\ Original scientific paper
}

\begin{abstract}
Objective of this study was to analyze the effect of the dairy farm on milk traits of cows in Vojvodina. The research was carried out on small farms with 10 to 20 cows, medium farms with 20 to 50 cows, and large farms with over 50 dairy cows. The study included registered animals of Simmental (SM) and Holstein-Friesian breed (HF; including Red Holstein) in the first lactation for traits of milk yield and yield and content of milk fat. Total of 1323 first lactations were analyzed. The average milk yield (both breeds) in the first lactation of 305 days was $6295 \mathrm{~kg}$ of milk with $234,3 \mathrm{~kg}$ of milk fat and average milk fat content of $3,74 \%$. Milk performance of cows varied significantly (CV=22,9\% and $\mathrm{SD}=1447,8)$, as well as milk fat yield $(\mathrm{CV}=21,6 \%$ and $\mathrm{SD}=50,8)$. Large farms produced in average $6534 \mathrm{~kg}$ of milk, medium farms $6347 \mathrm{~kg}$ and small farms $4717 \mathrm{~kg}$. Size of the farm exhibited significantly high effect on all observed traits, and the tendency was that farms with higher number of animals realize also higher average of production. Farm management and various breeding-zootechnical conditions present on farms had significant effect on milk performance of cows.
\end{abstract}

Key words: farm size, milk performance traits, Simmental and HolsteinFriesian breed

\section{Introduction}

Based on ten year period (1998-2008) of monitoring of milk production in Serbia, it can be observed that the average milk yield decreased by over $10 \%$. Decrease in milk production is recorded on the territory of Central Serbia, whereas in Vojvodina, which participates in total milk production with $20 \%$, the production increased by the same percentage. Considering that total number of dairy animals in the observation period was reduced, increase of production is based on increase of milk yield per dairy animal. Significant increase of yield was realized in herds carrying out selection 
measures and which are under continuous milk recording program. Control of animal productivity in AP of Vojvodina showed that in 2010 the average milk yield of dairy cows of HF breed was $5.505 \mathrm{~kg}$ with $202 \mathrm{~kg}$ of milk fat and average milk fat content of $3,36 \%$, whereas SM dairy animals under control produced in average $4.709 \mathrm{~kg}$ of milk with $181 \mathrm{~kg}$ of milk fat and average milk fat content of 3,52\%. Based on submitted applications for registration of producers of high quality breeding animals, it can be observed that production of milk in Vojvodina occurs on organized farms of various capacities. Predominant are small holdings with below 5 animals in breeding and such farms make $1 / 3$ of all farms. Share of holdings with 5 to 10 animals is also $30 \%$. Medium size holdings (from 10 to 50 dairy animals) are present with approx. $34 \%$, whereas the large producers (from 50 to 100 and over 100 dairy animals) are present with only approx. $5 \%$.

Present heterogeneity in regard to number of reared cows on farm, zootechnical and production conditions, as well as method and efficiency of resource utilization, significantly influence the lack of uniformity in the quantity of produced and delivered raw milk, which is in concordance with research results obtained by Anacker (2009) presented in Table 1.

Table 1. Impact of farm size on avarege milk yield in the federal state of Thuringen in Germany

\begin{tabular}{|l|c|c|c|c|c|}
\hline Farm size & Farm, $\mathrm{n}$ & Milk yield, kg & Milk fat, $\mathrm{kg})$ & Protein,kg & $\mathrm{ECM}(\mathrm{kg})$ \\
\hline below 49 & 97 & 7.265 & 4,31 & 3,38 & 7.498 \\
\hline from 50 to 99 & 63 & 7.845 & 4,10 & 3,41 & 7.934 \\
\hline from 100 to 199 & 62 & 8.479 & 4,04 & 3,39 & 8.514 \\
\hline from 200 to 499 & 115 & 8.703 & 4,08 & 3,40 & 8.779 \\
\hline over 500 & 49 & 8.826 & 4,09 & 3,39 & 8.911 \\
\hline
\end{tabular}

Source: Thüringer Landesanstalt für Landwirtschaft 2007

Research by Thomsen (2010) to certain extent confirms such trend (Table 2). Data presented in the table shows that the average milk yield of cows has slight increase on farms with 50 to 100 dairy animals. However, this increase is not linear and significantly distinct, even the average milk yield decreases insignificantly with the increase of number of dairy animal over 100 .

Table 2. Impact of farm size on average milk yield in the federal state of Schleswig-Holstein in Germany

\begin{tabular}{|l|c|c|}
\hline Farm size & Farm, $\mathrm{n}$ & Milk yield-ECM. (kg) \\
\hline below 50 & 48 & 8.675 \\
\hline from 50 to 75 & 168 & 8.531 \\
\hline from 75 to 100 & 162 & 8.778 \\
\hline from 100 to 150 & 151 & 8.701 \\
\hline over 150 & 63 & 8.717 \\
\hline
\end{tabular}

Source: Landwirtschaftskammer Schleswig-Holstein 2010 
Objective of this study was to analyze the variability of milk performance traits in registered SM and HF dairy animals under control, occurring as result of the impact of farm size, i.e. number of reared dairy animals, on the territory of AP Vojvodina.

\section{Materials and Methods}

In the study of the impact of dairy farm size on milk performance traits data obtained in the milk recording controls of SM and HF dairy animals in the first lactation was used. The study was carried out on small farms with 10 to 20 cows, medium size farms with 20 to 50 dairy cows and large farms with over 50 dairy cows. Milk recording controls were carried out by main breeding organizations of AP of Vojvodina. In total 1323 first lactations were analyzed. Detailed overview of the lactation distribution is given in the Table 3. All observed lactations were corrected to 305 day lactation. The following milk performance traits were analyzed: milk yield, milk fat yield and content.

Table 3. Distribution of lactations according to fixed factors

\begin{tabular}{|l|c|c|}
\hline Farm size & Breed & $\mathrm{n}$ \\
\hline \multirow{3}{*}{ Small farm } & $\mathrm{HF}$ & 64 \\
\cline { 2 - 3 } & $\mathrm{SM}$ & 73 \\
\cline { 2 - 3 } & sum & 137 \\
\hline \multirow{3}{*}{ Medium size farm } & HF & 303 \\
\cline { 2 - 3 } & SM & 61 \\
\cline { 2 - 3 } & sum & 364 \\
\hline \multirow{3}{*}{ Large farm } & HF & 728 \\
\cline { 2 - 3 } & SM & 94 \\
\cline { 2 - 3 } & sum & 822 \\
\hline
\end{tabular}

Rearing and zootechnical conditions of housing present on the farms included in the analysis differed and can be characterized as semi-extensive to intensive. System of housing of cows was basically in two variants, free system and tie system, with and without the free range. All farms used silage in cow nutrition throughout the year, certain farms used leguminous hay during winter, and during summer fresh green mass. Concentrated mixtures were also used according to the level of production.

Data was analyzed by using the software package Statistica ver. 10. General variability of observed traits was analyzed by using the descriptive statistical analysis and different sources of variability were defined by applying the general linear model GLM with fixed effect of the breed and farm size. 
a) observed traits (quantity of milk and milk fat $(\mathrm{kg})$ and content of milk fat $(\%))$

$$
\begin{array}{cl}
Y_{i j k}=\mu+F_{i}+R_{j} & +e_{i j k} \\
\text { where: } & \\
Y_{i j k} & =\text { value of observed trait, } \\
\mu & \text { = general mean value } Y_{i j k} \\
F_{i} & \text { = fixed effect of the farm i }(i=1,2,3), \\
R_{j} & \text { = fixed effect of the breed } j(j=1,2), \\
e_{i j k} & =\text { other random effects }
\end{array}
$$

\section{Results and Discussion} traits.

Table 4 presents the results of the descriptive statistical analysis of studied

Table 4. The average values and variability of expressed traits

\begin{tabular}{|l|c|c|c|c|c|}
\hline Trait & Average & Min & Max & SD & CV, \% \\
\hline Milk yield, kg & 6295 & 1852 & 10730 & 1447,8 & 22,9 \\
\hline Milk fat, kg & 234,3 & 74,2 & 534,5 & 50,8 & 21,6 \\
\hline Milk fat, \% & 3,74 & 2,64 & 5,39 & 0,26 & 6,9 \\
\hline
\end{tabular}

Based on studied sample, average milk yield of cows (both breeds) in the first lactation of 305 days was $6295 \mathrm{~kg}$ of milk with $234,3 \mathrm{~kg}$ of milk fat and average milk fat content of $3,74 \%$, which is significantly higher compared to average milk yield of total cow population in AP of Vojvodina (in 2008 the average milk yield was $3894 \mathrm{~kg}$ of milk). The lowest recorded milk yield on farms included in the study was $1852 \mathrm{~kg}$ and the highest was $10730 \mathrm{~kg}$, resulting in high value of the variation width of even $8878 \mathrm{~kg}$ of milk. Values of the variation coefficient and SD for milk yield trait were also very high $\mathrm{CV}=22,9 \%$ and $\mathrm{SD}=1447,8$. Such expressed variability indicates presence of considerable dispersion of values within the variation width, indicating further that unequal rearing conditions were present on farms, but also that dairy animals were exposed to different selection pressure. Considering that observed trait in general is characterized by medium heritability values, rearing in pure breed and implementation of adequate selection program would have positive effect on the success of selection. High variability was established for yield of milk fat $\mathrm{CV}=21,6 \%$ and $\mathrm{SD}=50,8$.

Contrary to established values of variation coefficient and SD for milk yield and yield of milk fat, values obtained for milk fat content were significantly lower - $\mathrm{CV}=6,9 \%$ and $\mathrm{SD}=0,26$. These lower values indicate that the variability of 
this trait is more under the influence of biological and breed characteristics of dairy cows, than rearing conditions present on the farms.

Table 5 presents the results of the analysis of the general linear model of studied milk performance traits in HF and SM dairy animals.

Table 5. Results of general linear models of analyzed traits

\begin{tabular}{|l|c|c|c|}
\hline \multicolumn{1}{|c|}{ Trait } & Milk Yield, kg & Milk fat, kg & Milk fat, $\%$ \\
\hline Source of variation & $59,49^{* *}$ & F value \\
\hline Farm & $90,59^{* *}$ & $56,62^{* *}$ & $38,51^{* *}$ \\
\hline Breed & $5,40^{* *}$ & $6,41^{* *}$ & $66,10^{* *}$ \\
\hline $\begin{array}{l}\text { Farm } \mathrm{x} \\
\text { Breed }\end{array}$ & \multicolumn{3}{|c}{$30,02^{* *}$} \\
\hline $\mathrm{P}<0,01^{* *}, \mathrm{p}<0,05^{*}, \mathrm{p}>0,05$ n.s.
\end{tabular}

Results of the general linear model indicate statistically highly significant effect of the breed and farm size, i.e. number of animals reared on the farm, as well as their mutual interaction in all studied milk performance traits. Production of milk in Vojvodina is organized in very different rearing and zootechnical conditions, therefore statistically highly significant sources of variation in regard to farm size were expected. Considering that the heritability values for milk performance traits range from very low to medium, applied farm management and production technology, which includes nutrition, housing, care, milking, etc., express strong effect on phenotypic variability of traits.

Present variability and the effect of farm size on milk yield of dairy cows can be observed on the Figure 1.

It can be observed, based on data presented in the diagram, that large farms with higher number of dairy animals produce in average more milk $(X=6534 \mathrm{~kg})$ compared to medium size farms $(6347 \mathrm{~kg})$ and small farms $(4717 \mathrm{~kg})$. On the other hand, production of milk on small farms shows fewer oscillations and is more uniform compared to medium size and large farms. The highest variability is observed on medium size farms. 


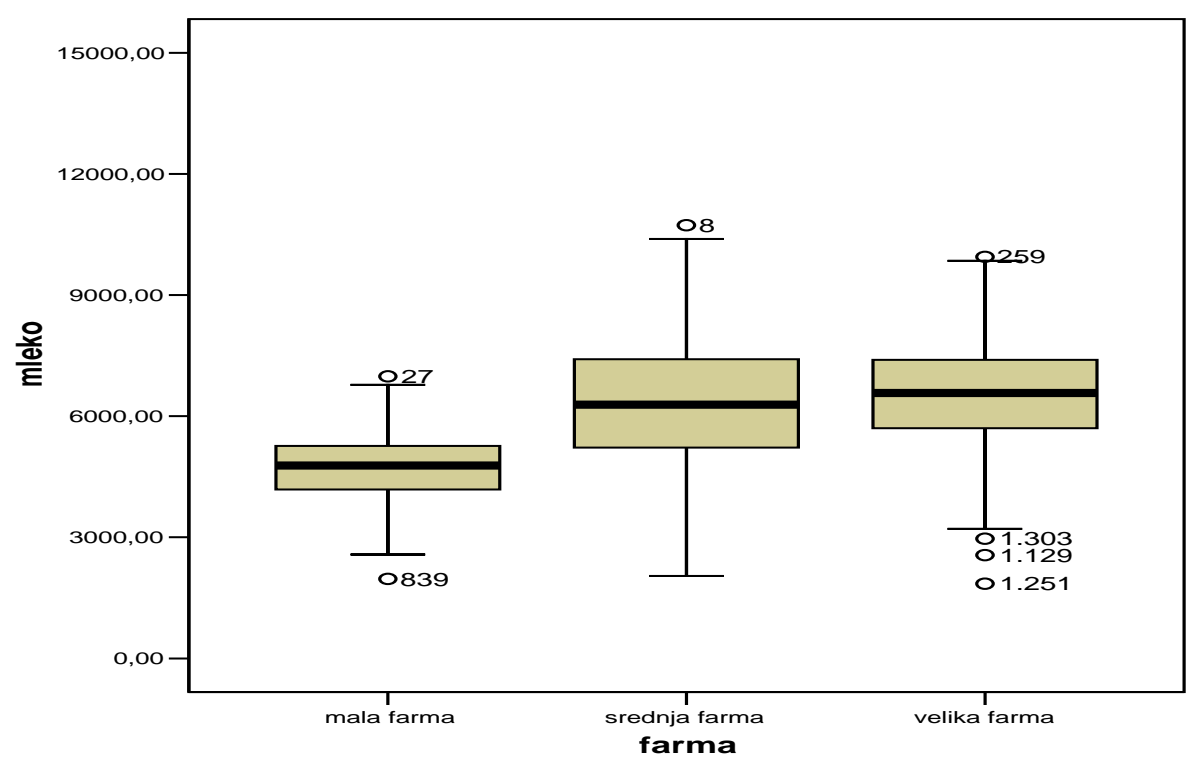

Figure 1. Variability of milk yield on studied farms

The research by Anacker (2009) in the federal state of Thüringen in Germany confirms this trend. Even though there are significant differences in the farm size, it can be observed in Table 1 that the small and medium size farms produced in average less milk compared to large farms with high number of dairy animals. The highest recorded difference in this case was even $1413 \mathrm{~kg}$ of FCM (fat corrected milk). The research by Thomsen (2010) to certain extent also confirm this trend (Table 2) since the average milk yield increase on farms of capacity of 50 to 100 cows, and decreased with the further increase of number of dairy animals. In concordance with these results are also results obtained in the study by Over (2008). Average milk yield increased on farms with 40 to 100 dairy animals (from $7155 \mathrm{~kg}$ to $7994 \mathrm{~kg}$ ), but with further increase of number of dairy animals on the farm, the average milk yield showed slight decrease.

\section{Conclusion}

Based on the research of the effect of the dairy farm size on milk performance traits in Vojvodina, it can be concluded that the milk yield of the part of dairy cattle population under milk recording control is significantly higher compared to average milk production in total dairy cow population. Expressed variability recorded for analyzed traits indicates the presence of significant heterogeneity in regard to implementation of rearing or zootechnical conditions on farms, as well as the method and efficiency of resource utilization. In that regard, 
further implementation of selection in accordance with the breeding program would be completely justified, with simultaneous improvement of nutrition condition, care, housing, etc. Farm size exhibited significant effect on all observed traits, and the tendency determined was that farms with higher number of dairy animals realize higher average milk yield. Results of studies carried out by other authors indicate that such trend is feasible only on farms of certain capacity, i.e. certain number of dairy animals in herd, and with further increase of number of animals on farm the decrease of production occurs. It can be assumed that the farm management also has significant effect on the production.

\title{
Uticaj veličine farmi na osobine mlečnosti krava
}

\author{
D. Kučević, S. Trivunović, M. Radinović, M. Plavšić, Z. Skalicki, P. Perišić
}

\section{Rezime}

Cilj rada je da se ispita uticaj veličine govedarske farme na osobine mlečnosti u Vojvodini. U odnosu na veličinu farme, ispitivanje je sprovedeno na malim farmama sa 10 do 20 krava, srednje velikim od 20 do 50 i velikim sa preko 50 krava. Ispitivanje je obuhvatilo umatičena grla simentalske (SM) i holštajnfrizijske rase (HF; uključujući i crveni holštajn) u prvoj laktaciji za osobine prinosa mleka, mlečne masti i sadržaja mlečne masti. Ukupno je analizirano 1323 prvih laktacija. Prosečna mlečnost krava (obe rase) u prvoj laktaciji za 305 dana je iznosila $6295 \mathrm{~kg}$ mleka sa $234,3 \mathrm{~kg}$ mlečne masti i prosečnim sadržajem masti od $3,74 \%$. Mlečnosti krava je značajno varirala $(\mathrm{CV}=22,9 \%$ i $\mathrm{SD}=1447,8)$ kao i prinos mlečne masti $(\mathrm{CV}=21,6 \%$ i $\mathrm{SD}=50,8)$. Velike farme su prosečno proizvele 6534 $\mathrm{kg}$, srednje $6347 \mathrm{~kg}$ i male $4717 \mathrm{~kg}$. Veličina farme je ispoljila signifikantno visok uticaj na sve posmatrane osobine a tendencija je da se na farmama sa većim brojem grla ostvaruje prosečno veća proizvodnja. Farmski menadžment i različiti odgajivačko zootehnički uslovi na farmama su ostvarili značajan uticaj na mlečnost krava.

\section{References}

ANACKER G. (2009): Analyse der Haltungsbedingungen für Kühe in Thüringer Milchproduktionsbetrieben. Thüringer Landesanstalt für Landwirtschaft. IZVEŠTAJ Glavne odgajivačke organizacije za APVza 2010 godinu OVER R. (2008): Ergebnisse der Rinderspezialberatung in Baden-Württemberg im Wirtschaftsjahr 2007/08, LEL Schwäbisch Gmünd. 
PANTELIĆ V., ALEKSIĆ S., STOJIĆ P., ĐURĐEVIĆ R., SAMOLOVAC LJ. (2010): The effect of breeding region and year on milk traits of Simmental bull dams. Biotechnology in Animal Husbandry, 26, 5-6, 287-295.

PANTELIĆ V., PLAVŠIĆ M., TRIVUNOVIĆ S., ALEKSIĆ S., SRETENOVIĆ LJ., OSTOJIĆ-ANDRIĆ D., NIKŠIĆ D. (2011): The evaluation of breeding value of Simmental bulls for milk performance in Serbia. Biotechnology in Animal Husbandry, 27, 2, 127-135.

SRETENOVIĆ LJ., NOVAKOVIĆ Ž., OSTOJIĆ D., PANTELIĆ V., ALEKSIĆ S., PETROVIĆ M.M., NOVAKOVIĆ M., MARINKOV G. (2010): Nova tehnologija dobijanja funkcionalne hrane - mleka i mesa poboljšanog kvaliteta. Biotechnology in Animal Husbandry, 26, spec.issue, 9-22.

STATISTIČKI GODIŠNJACI SRBIJE (1998-2009). Republički zavod za statistiku, Beograd.

THOMSEN J. (2010): Ergebnisse der Vollkostenauswertung der Rinderspezialberatungsringe in Schleswig-Holstein Auswertungsjahr 2009/2010 Landwirtschaftskammer Schleswig-Holstein, Abteilung Tierzucht und Tierhaltung, LVZ Futterkamp, 24327 Blekendorf 